\title{
Non-State Actors in International Law: A Rejoinder to Professor Thirlway
}

\author{
Cedric Ryngaert ${ }^{1}$
}

Published online: 7 April 2017

(C) The Author(s) 2017. This article is an open access publication

\begin{abstract}
That we consider the state-based system as best representing the individual is the product of a particular world view. A 'naturalized myth' renders inevitable the link between the physicality of the observable landscape and the state as a means of organizing a polity. This myth lingers on in international legal scholarship, although it has been debunked in other disciplines, notably in critical political geography. (Public) international lawyers can learn from their brethren in other disciplines and problematize the territorial state as a contingent political concept. Awareness of the social production of space may allow lawyers to imagine practices of resistance to the spatial status quo, in particular rights of non-state actors in the production of international law, alongside states, and obligations and responsibilities of non-state actors, especially where states have proved unable to properly assume roles of protection vis-à-vis individuals under their formal jurisdiction.
\end{abstract}

Keywords Non-state actors · Territoriality $\cdot$ Statehood $\cdot$ Space $\cdot$ Legal theory

It is rather unusual for an author to receive a lengthy written reaction, let alone in the form of an unsolicited academic contribution, to one's writings, even if it is the aim of academic publishing to stir up debate. Therefore, I am very grateful to Professor Thirlway for his reaction to my food-for-thought piece on non-state actors

The research which resulted in this publication has been funded by the European Research Council under the Starting Grant Scheme (Proposal 336230-UNIJURIS) and the Dutch Organization for Scientific Research under the VIDI Scheme (No. 016.135.322).

Cedric Ryngaert

c.m.j.ryngaert@uu.nl

1 Professor of Public International Law, Utrecht University, Utrecht, The Netherlands 
and international law, ${ }^{1}$ as well as to the Review for inviting me to write a short rejoinder. Professor Thirlway's article is a very thoughtful one, making a variety of points. I cannot possibly do justice to all the issues he has brought up in relation to my earlier article. Accordingly, I have chosen to engage more at length with the fundamental premise of the reaction: that the system of international law is, and can only be, based on states. This is a position which is descriptively relatively accurate, but it is in my view epistemically and normatively problematic.

Underlying Professor Thirlway's argument is an assumption that the state-based international system is both rational and just. In essence, Professor Thirlway argues that because individuals are always in a territorial space, their interests and needs are best represented and served by the sovereign state on whose territory they find themselves. In my view, however, this is begging the question. That we consider the state-based system as best representing the individual is the product of a particular world view which, assisted by the development of modern cartographic maps, considers territorially delimited states to be the only relevant actors that can have a legitimate representative function. This naturalized myth of the state, also characterized as 'the territorial trap', ${ }^{2}$ renders inevitable, and not subject to contestation, the link between the physicality of the observable landscape and the state as a means of organizing a polity. While this myth lingers on in international legal scholarship, ${ }^{3}$ it has been debunked in other disciplines, notably in critical political geography. ${ }^{4}$ The territorial state is ultimately a means of political technology which advances the self-serving goals of particular actors (elites) which do not necessarily represent the wishes of the people 'trapped' in a state's territory. Non-democratic, autocratic states may serve as proof thereof, but more fundamentally, from a historical perspective, the very rise of the territorial state in the early modern period points to the existence of prior, alternative forms of regulation that could be non-territorial or non-state based. ${ }^{5}$ As John Agnew has observed in this respect, 'political authority is not necessarily predicated on and defined by strict and fixed territorial boundaries'. ${ }^{6}$ It has been my hope that (public) international lawyers learn from their brethren in other disciplines and problematize the territorial state as a contingent political concept. That textbooks on international law define states as possessing territory and having sovereignty over it—as Professor Thirlway

\footnotetext{
1 Thirlway (2017).

2 Shah (2012), pp. 57-58 (the territorial trap 'is reproduced through the assumption that territory is the physical substratum of the state').

3 Professor Thirlway is stepping into this territorial trap where he writes as follows: 'The domination of the State in international law is thus by no means a quaint survival, nor the outcome of a power-struggle with NSAs that could have gone the other way, and could be refought to a different outcome; it is based on realities and physical fact.' Issue could be taken for that matter with the 'reality' and 'fact' that the state is a dominant political actor in global governance. Some multinational corporations, non-state armed groups and even non-governmental organizations rival states in wealth, power, and influence. It is this 'reality' which informs calls for an enhanced international legal status for non-state actors. Such a status could close the gap between the presence of power and the absence of law.

4 Elden (2013). See from a critical legal perspective, taking his cue from geography: Ford (1999).

5 I explore some of these alternatives, based on community, temporality, and justice in: Ryngaert (2017) (forthcoming).

6 Agnew (2005).
} 
highlights - is obviously true, but it simply exposes our discipline's territorial bias. It should not preclude a critical inquiry as to why territorial states have come to be considered as the main containers of political authority.

By restricting spatiality to the physical territorial presence of individuals, Professor Thirlway has obvious difficulties in conceiving of political authority in a space beyond the state. Every foothold is-literally- 'under the control of States as sovereigns over territory'. 'Counter-spatial' conditions that rival state-based territoriality, in particular non-state or global mechanisms of authority, need not be unimaginable, however. ${ }^{7}$

Let me embark on this argument by starting with a view which I share with Professor Thirlway, namely that 'to act effectively in space, occupation of a point or points in space [...] is essential'. Indeed, as Guilfoyle has observed, 'humans do not exist in pure space but rather in places which are "relational, historical and concerned with identity"; a place has a history and a set of social usages [...] Law operates through social agency: it operates on concrete or constructed places, not in abstract space'. ${ }^{8}$ This distinction between 'space' and 'place' is reminiscent of the French Marxist philosopher Henri Lefebvre's work. According to Lefebvre, space is socially produced through the interplay between actual spatial practices ('l'espace perçu) and conceptual spatial representations ('l'espace conçu'). ${ }^{9}$ It is ultimately the 'lived experience of everyday life' which enables 'abstract space' to be reproduced as concrete space, or 'place'. ${ }^{10}$

This reproduction does not happen naturally, of course, but is driven by selfinterested socio-political forces. Historical-material practices have then led to the construction of specific places, and the territorial state is one of them. It is precisely the awareness of the social production of space that allows us to imagine practices of resistance to the spatial status quo. It allows us, for instance, to imagine rights of non-state actors in the production of international law, alongside states, and to imagine obligations and responsibilities of non-state actors, especially where states have proved unable to properly assume roles of protection vis-à-vis individuals under their formal jurisdiction. Non-state actors, even when not exercising any sort of territorial control, also exist in a concrete space that is enclosed and delimited from other spaces. For instance, the spatial relations of multinational corporations are of a global, networked, nodal nature; they are delimited from other relations that have no bearing on the corporation's activities. From a normative perspective, such corporations may admittedly make use of state territory for the production of goods and services and are as such bound by state legislation (corporations are subjects of national law, as Professor Thirlway correctly points out). However, as their scope of action and relations are international, and their power sometimes dwarfs the power

\footnotetext{
7 Liste (2014), p. 3.

${ }^{8}$ Guilfoyle (2016), p. 199.

9 Lefebvre (1991), pp. 26, 33.

10 Jones (2016), p. 325 ('Place is about location, identity, relationships, and the experience of living somewhere. Places are experienced in different ways by different people, and asserting this plurality and specificity of place against the empty and singular form of space'), citing, apart from Lefebvre's work, also Massey (1993).
} 
of the state, they may create a sphere of non-state normativity. Such a sphere is not territorially delimited, but it is nevertheless spatially delimited as a functionally differentiated, relatively self-contained 'system' that is self-organized by corporate stakeholders. $^{11}$

This is not to say that non-state actors never aspire to the spatiality of the territorially organized state. Some do, and this is what I meant when writing that for some non-state actors, 'statehood may appear to be the ultimate prize'. De facto states, puppet states, putative states - entities which possess most but not all of the trappings of statehood-all crave for international recognition that renders them effective and legitimate states. ${ }^{12}$ Other organized non-state actors-mainly nongovernmental organizations and non-state armed groups-may only be interested in particular rights that have historically been associated with statehood, e.g., the right to participate in international conferences, organizations, and dispute-settlement mechanisms, or the right to use force and to be entitled to combatant privilege.

Other non-state actors - multinational corporations stand out in this respect-may not be interested at all in international legal status. By lobbying they may have an influence on state and international regulation anyway, while at the same time regulating themselves via non-traditional sources. This obviates the need for enhanced participatory rights at the classic intergovernmental level, whereas the obligations dimension of international legal status can in turn only adversely affect their operations and profit maximization. Calls for international legal status then typically emanate from other (civil society) non-actors, which use political platforms or the courts to make their case. Such efforts are understandably rebuffed by multinational corporations, but it is conspicuous-although evidently self-serving-that they may invoke to their benefit cognate concepts of state territoriality. For instance, they have resisted expanded extraterritorial jurisdiction on grounds of territorial jurisdiction and the principle of non-intervention, ${ }^{13}$ and they have resisted the imposition of direct human rights obligations on the ground that human rights have been conceived for vertical relationships of authority between a government and an individual rather than for horizontal relationships between non-state actors. ${ }^{14}$

In my article I wanted to draw attention to the rights and obligations of non-state actors under existing (positive) international law, as a foil for a more fundamental rethinking of our state-based concept of international legal personality. I venture to characterize the exposition of these existing arrangements as a critical redescription of the law. Sundhya Pahuja has defined this as 'an attempt to redefine [...] a world we take for granted, inviting it to be seen differently as a mode of political engagement'. ${ }^{15}$ With this redescription, I hope to have made visible the legal strides

\footnotetext{
11 Pulkowski (2014), pp. 200-201 (explaining that in systems theory geographic borders are less relevant and functional, while systemic delimitations are more important, as well as that in this theory formal state-engendered sources are not relevant, but instead that 'legal rules emerge on the basis of a selforganizing process of mutual constitution of legal acts and structures'). See for systems theory: Luhmann and Kastner (2004) and Teubner (1988).

12 Ivanel (2015).

13 Liste (2016), p. 235.

14 See for an interesting argument to overcome this verticality obstacle: Karavias (2013).

15 Pahuja (2013), p. 65.
} 
that non-state actors have made in the international legal system and to have highlighted that such strides - or conversely the absence of greater leaps-are the outcomes of the workings of power. ${ }^{16}$ This redescription allows us to better understand the current legal relationships between non-state actors and states, and between non-state actors among themselves, including state pushback. It also enables us to envisage, as an incremental step, an alternative world in which nonstate actors have acquired enhanced normative agency. I do not necessarily consider such a world to be normatively desirable, in the sense of being somehow 'better' than the current state-dominated system. My article was rather an exhortation not to take the latter system as self-evident but instead to further explore the potential of enhanced legal status for non-state actors in terms of the legitimacy and effectiveness of international law and global governance as a whole.

I have consciously refrained from making very specific suggestions for an adaptation or improvement of the international legal system, not just because such suggestions risk being haphazard, but, in all honesty, also because I struggle myself to envision particular aspects of an enhanced international legal status. For instance, there is no ready answer, as far as I am concerned, as to whether it is 'fair' to encumber corporations with direct human rights obligations, whether it is 'practical' or 'legitimate' to enhance the participatory rights of non-governmental organizations, or whether non-state armed groups should have the international 'right to rebel' against their own (repressive) government. ${ }^{17}$ This requires careful analysis that takes into account the unwelcome side-effects on the stability and justice of the international legal system. In fact, borrowing from Lefebvre, I mainly advocate a return to the conceptualization of 'abstract' spatial relations, and invite the reader to contemplate and evaluate alternative, concrete spatial relations in which non-state actors play a more prominent role. Or put differently, borrowing from Deleuze, Lévy, and Hildebrandt, I draw attention to 'the virtual' sphere of social relations and the contingency of different ways of actualization, with the state-based international regulatory sphere being just one of them. ${ }^{18}$ Virtualization of the governance problem, which the state system was meant to solve, could then open our minds to different actualizations of global governance, involving various non-state actors alongside states.

There is no doubt that I agree with Professor Thirlway's observation that nonstate actors 'do not need to be on a par with States'. In this respect, Professor Thirlway is possibly making too much of my statement that some non-state actors aspire to statehood. I do not argue that non-state actors should be allocated the same bundle of rights and obligations as states ('full legal personality'). However, building on existing arrangements, there may be room to consider expanding the catalogue of international rights and obligations for specific non-state actors, to the extent that this responds to the functional needs of the international community, to

\footnotetext{
$\overline{16}$ Orford (2012), pp. 609, 622, 624 (also relying on Michel Foucault).

17 See regarding the latter e.g. Paust (1983).

18 Deleuze (1994). Lévy (1998). I am grateful to Mireille Hildebrandt for pointing this out to me: Hildebrandt (2017).
} 
use the ICJ's terminology in the Reparation opinion. ${ }^{19}$ In the current statedominated system, such expansions will have to be decided on by states as the gatekeepers of the system. As states are not likely to drastically overhaul the system in ways that may ultimately work to their disadvantage, it is expected that the public international law system will remain state-centred, at least in the near future.

If that is the case, however, does public international law not risk relegating itself to the margins of the regulation of international affairs? Will parallel systems of non-state regulation and accountability not increase in number and scope and address a considerable number of international/global/transnational matters? Such systems already exist-think of transnational private regulatory arrangements coming about in multi-stakeholder dialogues-but they may well grow as a result of the dissatisfaction of non-state actors with state regulation, e.g., in the technological sector. $^{20}$ Non-state regulatory systems may not properly be called 'public international law', but they may have normative force, as Professor Thirlway would probably agree. ${ }^{21}$ Whether this 'pluralization' of international regulationwhich goes far beyond the fragmentation of international law $^{22}$ - is something to lament is an open question. Still, there is an inherent attractiveness in finding, or creating, some unity in the diversity: to connect different regulatory systems to each other, if only to prevent normative overlap and conflict in the legal governance of human problems. This also explains why Philip Jessup, back in 1956, coined the term 'transnational law', to denote not only the law governing the 'society of states' (public international law) but also the rules governing 'transnational situations', that 'involve individuals, corporations, states, organizations of states, or other groups' ${ }^{23}$ A reconsideration and actualization of Jessup's proposal may well be called for. ${ }^{24}$

Given the literary references which have infused the arguments made in our respective contributions, let me end by reinterpreting the two lines of T.S. Eliot's long poem The Lovesong of J. Alfred Prufrock, quoted at the end of Professor Thirlway's article: 'No! I am not Prince Hamlet, nor was meant to be; Am an attendant lord, ...' ${ }^{25}$ Sure enough, these lines could be interpreted, when applied by analogy to non-state actors, as non-state actors acquiescing in their destiny as secondary actors on the world stage in the shadow of the society of states. This

\footnotetext{
${ }^{19}$ Reparations for Injuries Suffered in the Service of the United Nations, Advisory Opinion, ICJ Reports 1949, p. 187.

20 Ryngaert and Zoetekouw (2017) (forthcoming).

21 Compare Professor Thirlway's argument that an agreement concluded between a state and a non-state actor, or between non-state actors would not normally be called a 'treaty', but would nevertheless have legal force.

22 See on the fragmentation of international law: Report of the International Law Commission 2006, Fifty-eighth session, UN General Assembly Official Records, Fifty-Eighth Session, UN Doc. No. A/CN.4/L.682.

23 Jessup (1956), p. 2.

24 There is in fact no shortage of interest in Jessup's work. See, e.g., 60 years after publication: Conference on Jessup's Bold Proposal: Engagements with Transnational Law, Transnational Law Institute, King's College London, 2-3 July 2016, available at http://www.kcl.ac.uk/law/tli/events/jessupconference.aspx; and 50 years after publication: http://www.wirtschaftsrecht.uni-halle.de/sites/default/ files/altbestand/Heft50.pdf.
}

25 The Lovesong of J. Alfred Prufrock (1920), 11. 111-3. 
secondary role is indeed the common understanding of the term 'attendant lord', as a lord who literally attends to the desires of his overlord. In that sense, the non-state actor is in fact not just a secondary actor, but also one who has little agency of his own. His role is to reinforce, or at least not to undermine the position of his statemaster, who may expect something in return for conferring legal status on the nonstate actor. However, there is another, more etymological way of interpreting the term 'attendant lord': a lord who is waiting (from the French 'attendre'). The female equivalent of 'attendant lord', 'lady-in-waiting', is even more explicit in this regard. Perhaps these attendant lords and ladies-in-waiting are only biding their time, waiting for the day of emancipation and ascendancy to power. It would not be the first time in history that attendants or companions seize power; think of the Mamluks, slaves who dominated the military in Islamic societies, who overthrew the Ayyubids dynasty in 1250, and claimed for themselves the Sultanate of Egypt and the Levant. ${ }^{26}$ What is key is that these actors are bothered by political questions, ${ }^{27}$ and are willing to challenge an existing system that insufficiently accommodates their concerns and demands. Prufrock himself surely met the first condition. While having an inferiority complex towards Hamlet, he 'is bothered by the big questions', and 'does not withdraw entirely into tea and toast'. ${ }^{28}$ Mounting a challenge against the system, he does not. But it is hardly certain that Prufrock's acquiescence will be imitated by non-state actors whose desire for more autonomy is hampered by the current system of international law.

Open Access This article is distributed under the terms of the Creative Commons Attribution 4.0 International License (http://creativecommons.org/licenses/by/4.0/), which permits unrestricted use, distribution, and reproduction in any medium, provided you give appropriate credit to the original author(s) and the source, provide a link to the Creative Commons license, and indicate if changes were made.

\section{References}

Agnew J (2005) Sovereignty regimes: territoriality and state authority in contemporary world politics. Ann Assoc Am Geogr 95(2):437-461

Akkerman N, Houben B (eds) (2013) The politics of female households: ladies-in-waiting across early modern Europe. Brill, Leiden

Deleuze G (1994) Difference and repetition. Columbia University Press, New York

Elden S (2013) The birth of the state. University of Chicago Press, Chicago

Ford R (1999) Law's territory (a history of jurisdiction). Michigan Law Rev 97(4):843-930

Guilfoyle D (2016) Reading The City and the City as an international lawyer: reflections on territoriality, jurisdiction and transnationality. Lond Rev Int Law 4(1):195-207

Hildebrandt M (2017) The virtuality of territorial borders. Utrecht Law Rev, vol 13 (forthcoming)

Ivanel B (2015) Puppet states: a growing trend of covert occupation. Yearb Int Humanit Law 18:43-65 Jessup P (1956) Transnational law. Yale University Press, New Haven

Jones H (2016) Lines in the ocean: thinking with the sea about territory and international law. Lond Rev Int Law 4(2):307-343

\footnotetext{
26 Philipp and Haarmann (1998).

27 See for an analysis of the political role of ladies-in-waiting in a male-dominated society: Akkerman and Houben (2013).

28 Mousley (2016), p. 55. However, "not only is the asking of them continually deferred, the questions themselves are never explicitly formulated...' (p. 54).
} 
Karavias M (2013) Corporate obligations under international law. Oxford University Publishing, Oxford Lefebvre H (1991) The production of space. Blackwell Publishing, Oxford

Lévy P (1998) Becoming virtual. Reality in the digital age. Plenum Trade, New York

Liste P (2014) Transnational human rights litigation and territorialised knowledge: Kiobel and the 'politics of space'. Trans Legal Theory 5(1):1-19

Liste P (2016) Geographical knowledge at work: human rights litigation and transnational territoriality. Eur J Int Relat 22(2):217-239

Luhmann N, Kastner F (2004) Law as a social system. Oxford University Press, Oxford

Massey D (1993) Power-geometry and a progressive sense of place. In: Bird J, Curtis B, Putnam T, Robertson G, Tickner L (eds) Mapping the futures: local cultures, global change. Routledge, London, pp 59-69

Mousley A (2016) Chapter three: felt significance. In: Freer S, Bell M (eds) Religion and myth in T. S. Eliot's poetry. Cambridge Scholars Publishing, Newcastle upon Tyne, pp 49-64

Orford A (2012) In praise of description. Leiden J Int Law 25(3):609-625

Pahuja S (2013) Laws of encounter: a jurisdictional account of international law. Lond Rev Int Law 1(1):63-98

Paust J (1983) The human right to participate in armed revolution and related forms of social violence: testing the limits of permissibility. Emory Law J 32:545-582

Philipp T, Haarmann U (1998) The Mamluks in Egyptian politics and society. Cambridge University Press, Cambridge

Pulkowski D (2014) Regime conflict. Oxford University Publishing, Oxford

Ryngaert C (2017) Territory in the law of jurisdiction: imagining alternatives. Neth Yearb Int Law 2016, vol 47 (forthcoming)

Ryngaert C, Zoetekouw M (2017) The end of territory? The re-emergence of community as a principle of jurisdictional order in the Internet Era. In: Kohl U (ed) The Net and the State. Cambridge University Press, Cambridge (forthcoming)

Shah N (2012) The territorial trap of the territorial trap: global transformation and the problem of the state's two territories. Int Polit Sociol 6:57-76

Teubner G (1988) Autopoietic law: a new approach to law and society. Walter de Gruyter, Berlin

Thirlway H (2017) Non-state actors: a response to Professor Ryngaert. Neth Int Law Rev. doi:10.1007/ s40802-017-0081-6 